\title{
Occurrence of Peronosclerospora sorghi in Uganda
}

G. Bigirwa, Former Graduate Student, and E. Adipala, Plant Pathologist, Department of Crop Science, Makerere University, P.O. Box 7062, Kampala, Uganda; and J. P. Esele, Plant Pathologist, Serere Agricultural and Animal Production Research Institute, Soroti, Uganda

\begin{abstract}
Bigirwa, G., Adipala, E., and Esele, J. P. 1998. Occurrence of Peronosclerospora sorghi in Uganda. Plant Dis. 82:757-760.

A study was conducted to determine the occurrence and severity of sorghum downy mildew on three major hosts (maize, sorghum, and Johnson-grass) in Uganda. Five surveys were conducted in four growing seasons, between 1994 and 1995. The disease was encountered in 11 of the 22 districts surveyed. In the majority of the areas, incidence was less than $10 \%$, but it was significantly higher $(P<0.05)$ in the second season of 1994 than in the first season of 1995. Soil type significantly $(P=0.001)$ influenced the incidence of sorghum downy mildew, with high incidence being associated with sandy soils, followed by loamy soils, and lowest incidence in clay soils. Incidence, shredding, and oospore production were comparatively higher on sorghum and Johnson-grass than on maize.
\end{abstract}

Additional keywords: collateral host, conidia, epidemiology, yield loss

Sorghum downy mildew of maize, caused by Peronosclerospora sorghi, is widespread and sporadic in East Africa (5). In Uganda, however, information indicates the disease is restricted mostly to sorghum in four districts of the country: Soroti, Kumi, Pallisa, and Tororo. According to Doggett (5), sorghum downy mildew is of minor importance on maize but of major concern on sorghum in the whole of East Africa. Recent reports, however, suggest that sorghum downy mildew may be on the increase in Uganda and may be causing severe yield losses in maize (G. Bigirwa, unpublished).

The objective of the study, therefore, was to determine the occurrence, distribution, and severity of sorghum downy mildew in Uganda on its various hosts.

\section{MATERIALS AND METHODS}

Survey. Field surveys were conducted to establish the occurrence of sorghum downy mildew on maize (Zea mays L.), Johnsongrass (Sorghum halepense (L.) Pers.), and sorghum (Sorghum bicolor (L.) Moench). Five separate surveys were conducted between 1994 and 1995 to cover major maize growing districts of Uganda. The first survey was conducted during the first season (March to June) of 1994 and covered 14 districts: Mpigi, Mukono, Jinja, Iganga, Tororo, Mbale, Soroti, Kumi, Lira,

Corresponding author: E. Adipala

E-mail: acss@starcom.co.ug

Accepted for publication 9 March 1998.

Publication no. D-1998-0429-01R

(C) 1998 The American Phytopathological Society
Masindi, Hoima, Mbarara, Ntungamo, and Kabale. During the second season of 1994 (September to December), two surveys were conducted when most plants had about 12 leaves (V12 stage) and at dough stage, when kernels were filled with a white paste. The embryo was about half as wide as the kernel (R4) (11). Twenty-two districts were visited: Mpigi, Mukono, Jinja, Iganga, Tororo, Mbale, Kapchorwa, Kumi, Soroti, Lira, Apac, Masindi, Hoima, Luwero, Masaka, Mbarara, Ntungamo, Kabale, Kasese, Kabarole, Mubende, and Arua. The same districts were surveyed during the first and second seasons of 1995. The districts surveyed during the study are shown in Figure 1.

Maize and sorghum fields were sampled every $20 \mathrm{~km}$ of a road system across each district. However, when sorghum downy mildew was seen, even if it was not during one of the systematic stops, sampling was done. Incidence was obtained by counting the number of infected plants out of a random sample of 100 plants in four different positions in each field. Fields with Johnson-grass were also sampled for sorghum downy mildew. Four quadrats, each measuring $1.5 \times 1.5 \mathrm{~m}$ and spaced approximately $10 \mathrm{~m}$ apart, were used. Infected Johnson-grass plants in each quadrat were counted and expressed as a percentage of the total number of plants.

Data on soil type were also taken. Soil texture was determined as described by Cardwell and Lane (3), by wetting a pinch of soil with some drops of water and trying to form it into a ball. If a clean, sticky ball formed, the main component was clay. If wet soil fell through the fingers, it was mostly sand. If it became sticky, and smeared instead of rolling into a ball, it was mostly loam. Representative soil samples were taken to Kawanda Agricultural Research Institute for confirmation of soil classes.

Attempts were also made to establish the presence of conidia on leaf surfaces. Only plants still green were examined. In some cases, conidia were mounted on slides and taken to the laboratory for identification and confirmation of the pathogen.

Search for oospores in leaves. Senescing plants were preferred for oospore searching. Leaf samples were collected from plants with shredded leaves that were suspected to have oospores. Samples were obtained from infected maize, sorghum, and Johnson-grass. Small leaf samples were cut and put in paper envelopes for laboratory examination. A total of 89 samples from maize, 128 from sorghum, and 103 from Johnson-grass were collected. These samples were macerated, mounted in lactophenol blue, and examined under a compound microscope at 100 and 400 magnification for presence of oospores.

Overall incidence values for each district per season were derived from the means of fields. Data generated were analyzed with Statistical Analysis System software (SAS Institute, Cary, NC) using the mean procedure (PROC MEAN). Means were compared using Fisher's protected least significant difference (LSD) test at the 5\% probability level (17).

\section{RESULTS}

Microscopic examination of conidia mounted on slides obtained from maize, sorghum, and Johnson-grass revealed that they fit the description of $P$. sorghi: conidia suborbicular varying from 15 to $28 \times 15$ to $26.9 \mu \mathrm{m}$, hyaline, with a thin wall, continuous at the apex, unmodified, and without any papilla of dehiscence, borne on long, thick, dichotomously branched conidiophores (12-14). Oospores were present in all three hosts, but they could be found more often in sorghum plants than in Johnson-grass or maize. In maize, they were found in a few locations: at Serere in Soroti, Nazaretti in Mpigi, and Ikulwe in Iganga (Table 1).

Sorghum downy mildew was encountered in 11 of the 22 districts surveyed: Mpigi, Jinja, Iganga, Tororo, Mbale, Kumi, Soroti, Masindi, Luwero, Mubende, and Arua (Table 2). In most districts, differences in incidence between districts and between seasons were significant $(P=$ 0.051 and 0.001 , respectively). The highest 


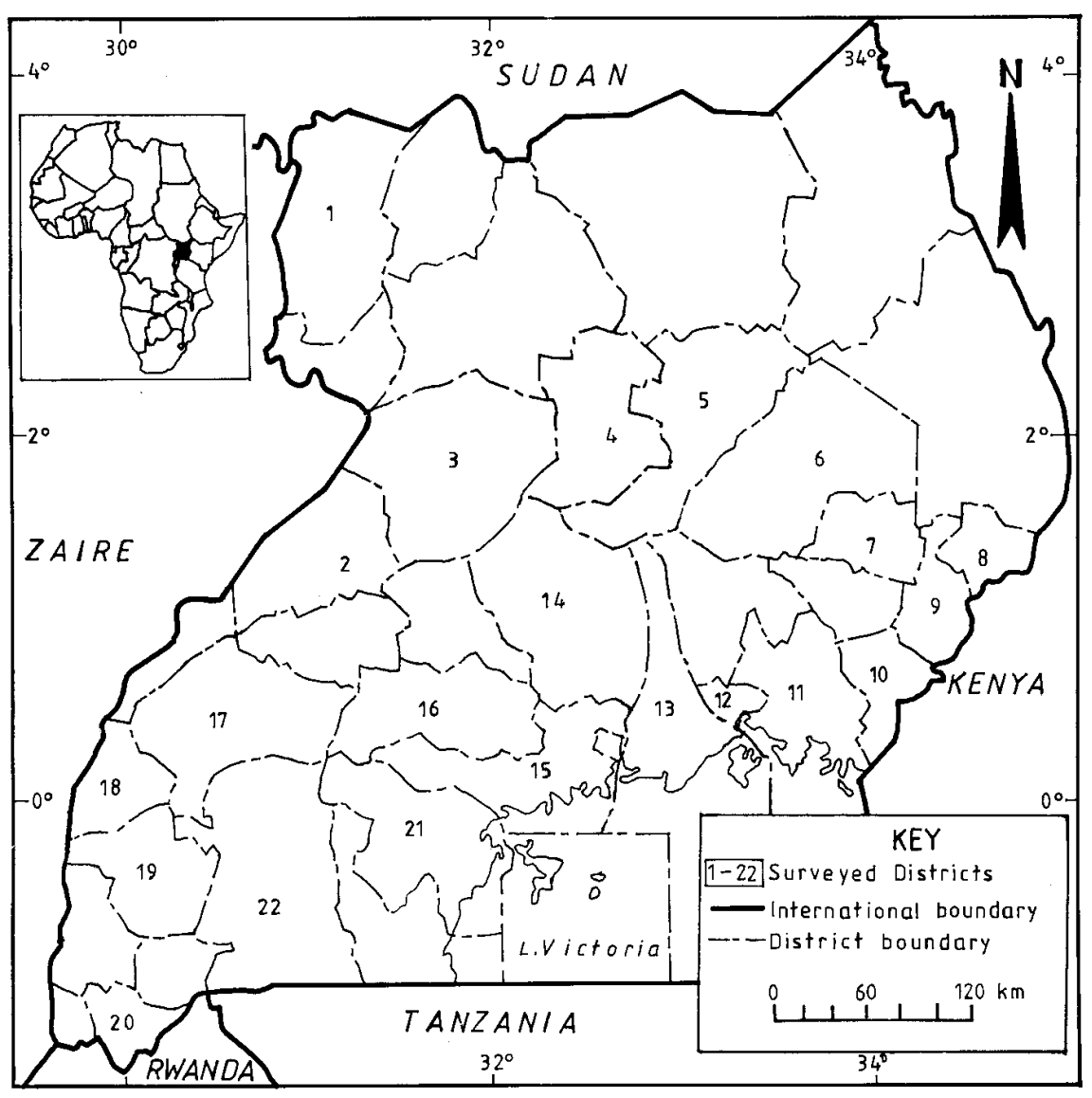

Fig. 1. Location of surveyed districts of Uganda for prevalence of sorghum downy mildew, 1994 to 1995. 1 Arua, 2 Hoima, 3 Masindi, 4 Apac, 5 Lira, 6 Soroti, 7 Kumi, 8 Kapchorwa, 9 Mbale, 10 Tororo, 11 Iganga, 12 Jinja, 13 Mukono, 14 Luwero, 15 Mpigi, 16 Mubende, 17 Kabarole, 18 Kasese, 19 Bushenyi, 20 Kabale, 21 Masaka, 22 Mbarara.

Table 1. Presence of oospores of Peronosclerospora sorghi in different districts of Uganda

\begin{tabular}{lccc}
\hline & \multicolumn{3}{c}{ Host } \\
\cline { 2 - 4 } District & Maize & Sorghum & Johnson grass \\
\hline Jinja & $-^{\mathrm{a}}$ & - & + \\
Iganga & + & + & + \\
Tororo & - & + & + \\
Mbale & + & + & - \\
Soroti & + & + & - \\
Mpigi & + & + & + \\
Masindi & - & + & - \\
Arua & - & + & - \\
Others & - & - & - \\
\hline
\end{tabular}

$\mathrm{a}_{-}=$oospores not present, $+=$oospores present.

${ }^{b}$ Other districts (Luwero, Mubende, Kumi) with the disease but with no oospores found.

Table 2. Incidence of sorghum downy mildew in Uganda, 1994 to $1995^{\text {a }}$

\begin{tabular}{lccccccc}
\hline & Fields & \multirow{2}{*}{$\begin{array}{c}\text { Fields } \\
\text { District }\end{array}$} & $\begin{array}{c}\text { Proportion of } \\
\text { surveyed }\end{array}$ & infected & \multicolumn{4}{c}{ Incidence (\%) class $^{\mathbf{b}}$} \\
\cline { 7 - 8 } \cline { 5 - 7 } fields affected (\%) & $\mathbf{1 - 1 0}$ & $\mathbf{1 1 - 2 0}$ & $\mathbf{2 1 - 3 0}$ & $\mathbf{3 1 - 4 0}$ \\
\hline Masindi & 37 & 8 & 22 & 7 & 1 & 0 & 0 \\
Soroti & 17 & 8 & 47 & 8 & 0 & 0 & 0 \\
Mubende & 24 & 1 & 04 & 1 & 0 & 0 & 0 \\
Mbale & 42 & 27 & 64 & 23 & 4 & 0 & 0 \\
Arua & 16 & 2 & 13 & 2 & 0 & 0 & 0 \\
Iganga & 40 & 14 & 35 & 12 & 1 & 0 & 1 \\
Jinja & 38 & 9 & 24 & 9 & 0 & 0 & 0 \\
Mpigi & 39 & 12 & 31 & 12 & 0 & 0 & 0 \\
Kumi & 21 & 10 & 48 & 8 & 1 & 1 & 0 \\
Tororo & 39 & 11 & 28 & 10 & 0 & 1 & 0 \\
Luwero & 34 & 4 & 12 & 4 & 0 & 0 & 0 \\
Total & 34 & 7 & 106 & 96 & 7 & 2 & 1 \\
\hline
\end{tabular}

a Based on five surveys conducted on maize, sorghum, and Johnson-grass in four seasons.

${ }^{\mathrm{b}}$ Disease incidence within a field. incidence was observed in the second season of 1994, followed by the first season of 1995. On average, Iganga and Mbale had the highest incidence, although slight variations were observed between seasons. For instance, Jinja had the highest incidence during the first rains of 1994, while for the second rains of 1995, the highest incidence of sorghum downy mildew was recorded in Soroti (Fig. 2).

Incidence of sorghum downy mildew varied significantly $(P=0.01)$ on the three hosts. On average, the incidence of sorghum downy mildew was highest on sorghum and least on maize. However, there was more sorghum downy mildew on Johnson-grass than on maize during the first season of 1995, and markedly more than on both maize and sorghum during the second season of 1995 (Fig. 3).

The highest number of maize fields infected with $P$. sorghi was recorded in Mbale (64\%), while for sorghum the highest number was in Soroti $(47 \%)$. In the case of Johnson-grass, Luwero had the highest number of infected fields (12\%).

Occurrence of sorghum downy mildew was also related to the soil types in the surveyed areas. Soil type significantly $(P=$ 0.001) influenced the incidence of sorghum downy mildew. A high incidence of sorghum downy mildew was associated with sandy soils, followed by loamy, and was least in clay soils (Fig. 4).

\section{DISCUSSION}

The occurrence and distribution of sorghum downy mildew on maize, sorghum, and Johnson-grass was investigated in Uganda over four seasons. We detected sorghum downy mildew in 11 of the 22 districts surveyed. Only four districts were previously known to have the disease (5). Thus, sorghum downy mildew has a wider distribution in the country than previously thought (5). Overall, however, incidence of sorghum downy mildew was low in fields where the disease was found. The disease was more frequently encountered on sorghum and Johnson-grass than on maize. While the low incidence might give the impression of low economic importance of the disease, it should be noted that $P$. sorghi produces large quantities of asexual and sexual inoculum and is, therefore, a potential danger to both maize and sorghum production in Uganda. In Nigeria, for example, the disease progressed from being of no economic importance for several years to a chronic yield constraint today (7). Presently, the disease is reported to cover $10 \%$ of Nigeria's maize growing areas, and it is estimated to be spreading at a rate of $50 \mathrm{~km}$ per year $(2,18)$.

Areas affected by sorghum downy mildew in Uganda have similar agro-ecologies to some of the areas currently free of the disease. This implies that, if not controlled, the disease will likely increase and spread to new areas. Periodic surveys will have to 
be undertaken along the epidemic frontiers to monitor the spread of the disease and to advise extension staff and farmers about the disease and ways to control it.

From what is known about sorghum downy mildew, any maize or sorghum plant infected early usually produces no yield at all, and a linear relationship has been demonstrated between disease incidence and yield loss $(1,4,19)$. Assuming this relationship is correct and using the mean incidence of systemic infection per site within the epidemic zone, the estimated yield loss to total production of maize and sorghum in Uganda was $4.0 \%$ in 1994 and $4.1 \%$ in 1995.

In the current study, sorghum downy mildew was not restricted to sorghum growing districts of Soroti, Kumi, Pallisa, and Tororo but occurred country-wide. There are no previous records of sorghum downy mildew on maize in other districts of Uganda apart from Soroti, Kumi, Pallisa, and Tororo. It is probable that sorghum downy mildew was undetected for a long time, but with the introduction of new maize genotypes, some of which are susceptible, sorghum downy mildew has spread to new areas. A similar situation was reported from Mexico in 1973, where the introduction of new grain sorghum hybrids exacerbated sorghum downy mildew (6).

Johnson-grass is commonly found in maize and sorghum fields in Uganda, and in a number of areas, it was infected by $P$. sorghi. Johnson-grass may therefore be an important collateral host of $P$. sorghi in Uganda.

Oospore production in maize is very rare (15). Indeed, Olanya and Fajemisin (10) could not find oospores in maize in Nigeria. In this study, however, oospores were present in maize, sorghum, and Johnsongrass, but only in certain localities of the country. Oospores serve as a primary means of pathogen survival during the off season (20) and as primary sources of inoculum during the growing period (2). Conidia were readily found on maize, sorghum, and Johnson-grass. In swampy areas where maize is grown almost all year round and where land under fallow is dominated by Johnson-grass for several seasons, conidia are likely to be responsible for the disease buildup.

Although Kwaje (9) reported the occurrence of sorghum downy mildew on sorghum in Kabale district in southwestern Uganda, no case of the disease was observed in this study. The reason for the absence of disease is not known, but it is possible that farmers in these areas are no longer growing sorghum downy mildewsusceptible sorghums. Jones (8) and Singh (16) have also reported cases where no sorghum downy mildew developed in previously infected fields. It is also possible that conditions in Kabale, being too cold, do not favor the development of sorghum

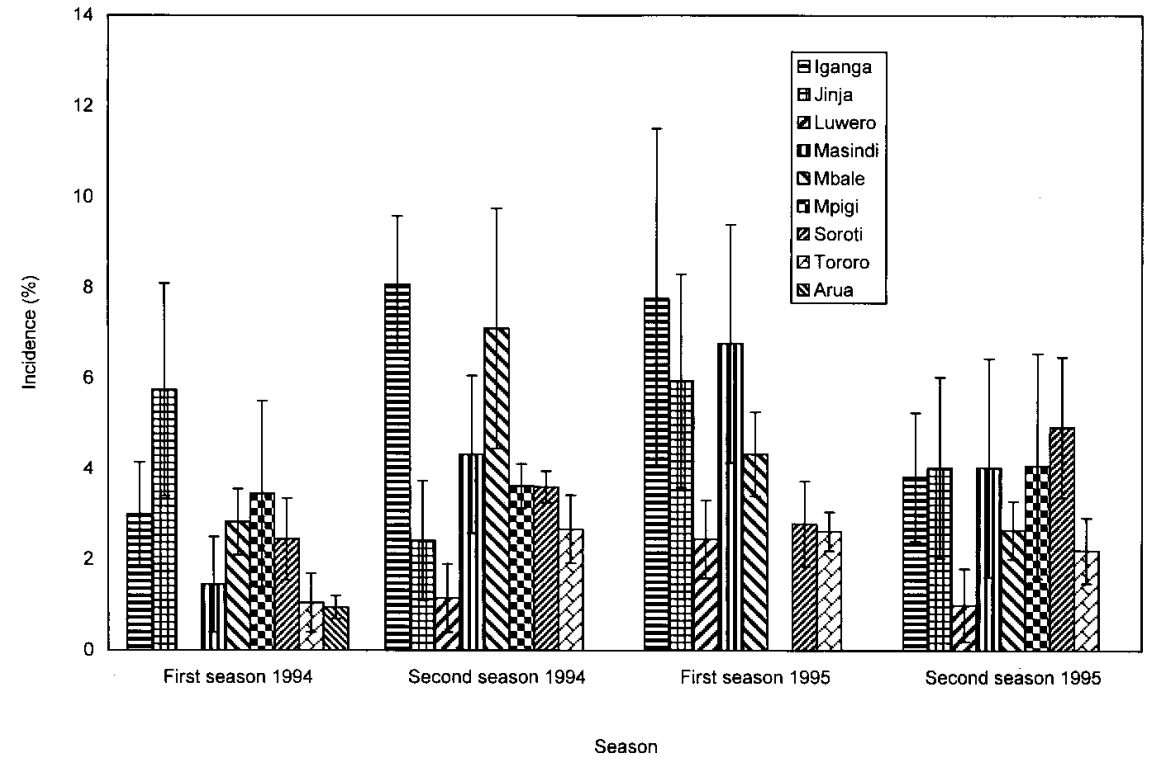

Fig. 2. Mean incidence of sorghum downy mildew in selected districts of Uganda, 1994 to 1995. Bars indicate standard errors.

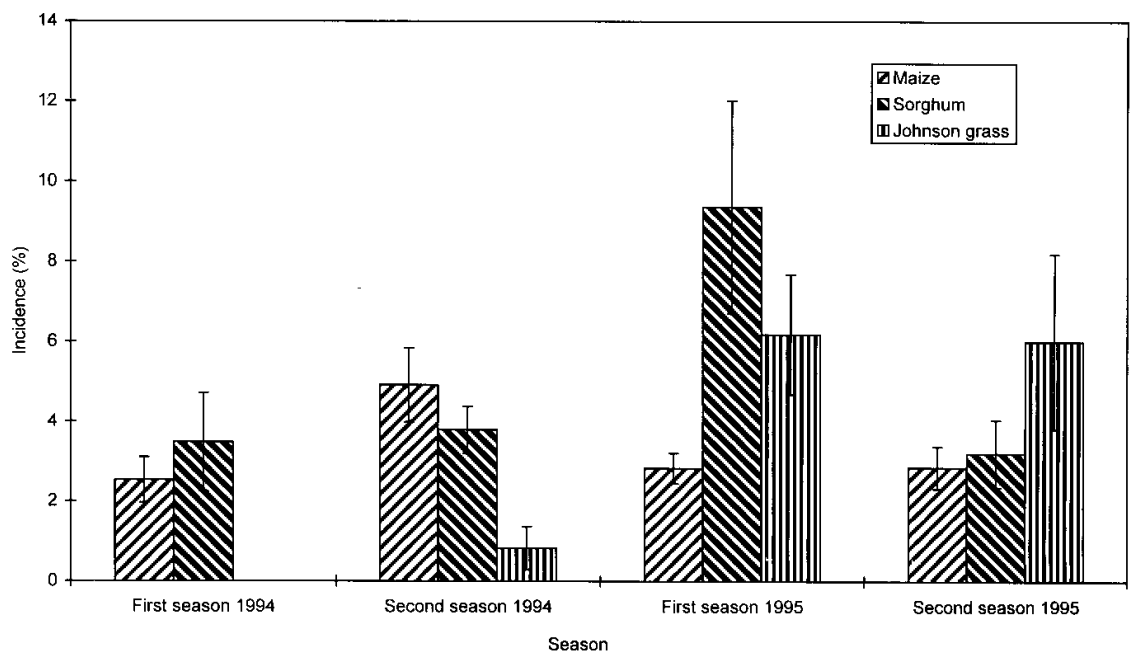

Fig. 3. Relative occurrence of sorghum downy mildew on maize, sorghum, and Johnson-grass in Uganda, 1994 to 1995 . Bars indicate standard errors.

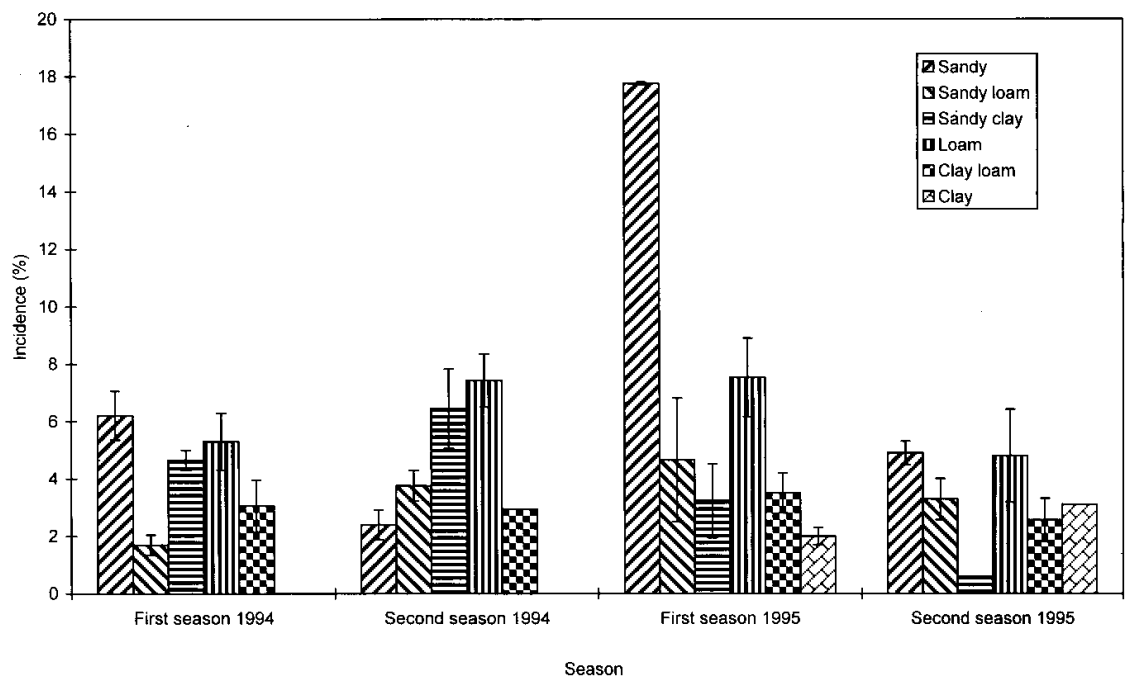

Fig. 4. Influence of soil type on incidence of sorghum mildew in Uganda. Bars indicate standard errors. 
downy mildew. Given these two conflicting findings, sorghum downy mildew status in Kabale needs revisiting.

\section{ACKNOWLEDGMENTS}

This study was supported by a grant to the first author from the International Foundation for Science (IFS), Stockholm, Sweden. Additional support was provided by CIDA/CIMMYT through the East African Cereals Project.

\section{LITERATURE CITED}

1. Anaso, A. B., Emechebe, A. B., Tyagi, P. D., and Manzo, S. K. 1989. Assessment of loss in yield due to sorghum downy mildew (Peronosclerospora sorghi) of maize in Nigeria guinea Savannah. Trop. Pest Manage. 35:301-303.

2. Cardwell, K. F. 1995. The nature of the downy mildew of maize caused by Peronsclerospora sorghi. Pages 15-25 in: Proc. Afr. Conf. Workshop Eradication Strategy Maize Downy Mildew. IITA, Ibadan, Nigeria.

3. Cardwell, K. F., and Lane, J. E. 1995. Effect of soils, cropping system and host phenotype on incidence and severity of Striga gesnerioides on cowpea in West Africa. Agric. Ecosys. Environ. 53:253-262.

4. Craig, J., Odvody, G. N., Wall, G. C., and Meckenstock, D. H. 1989. Sorghum downy mildew loss assessment with near isogenic sorghum populations. Phytopathology 79:448451.

5. Doggett, H. 1970. Downy mildew in East Africa. Ind. Phytopathol. 23:350-355.

6. Frederiksen, R. A., Bockholt, A. J., Rosenow, D. T., and Reyes, L. 1970. Problems and progress of sorghum downy mildew in the United States. Ind. Phytopathol. 23:221-338.

7. IITA. 1992. International Institute of Tropical Agriculture, Annu. Rep. Ibadan, Nigeria. pp. 25-27.

8. Jones, B. L. 1971. The mode of Sclerospora sorghi infection of Sorghum bicolor leaves. Phytopathology 61:406-408.

9. Kwaje, S. L. 1975. Downy mildew of sorghum in Uganda. M.Sc. Agric. thesis. Makerere University, Kampala, Uganda.

10. Olanya, O. M., and Fajemisin, J. M. 1993. Host-range and survival studies of Peronosclerospora sorghi at two locations in Nigeria. Int. J. Pest Manage. 39:13-18.

11. Ritchie, W., Hanway, J. J., and Benson, G. O. 1989. How a corn plant develops. Special Report No. 48. Iowa State University, Ames.

12. Saffeeulla, K. M., and Shetty, S. H. 1977. Seed transmission of sorghum downy mildew on corn. Seeds Farms 3:21-25.

13. Shaw, C. G. 1975. The taxonomy of graminicolous downy mildews, with emphasis on those attacking maize. Trop. Agric. Res. 8:47-55.
14. Shaw, C. G. 1978. Peronosclerospora spp and other downy mildews of the graminaea. Mycologia 70:597-605.

15. Shurtleff, M. C. 1980. Compendium of Corn Diseases. 2nd ed. American Phytopathological Society, St. Paul, MN. pp. 29-36.

16. Singh, J. P. 1975. Relative disease reaction of maize varieties to downy mildew nursery (1969-1973). Trop. Agric. Res. 8:129-152.

17. Steel, R. G. D., and Torrie, J. H. 1980 Principles and Procedures of Statistics. A Biometric Approach. 2nd ed. McGraw-Hill, New York.

18. Usman, I. 1995. The role of the national seed service in strategies of maize downy mildew control in Nigeria. Pages 34-40 in: Proc. Afr. Conf. Workshop Eradication Strategy Maize Downy Mildew, Ibadan, Nigeria.

19. Wall, G. C., Frederiksen, R. A., Craig, J. D., and Jeger, M. J. 1992. Epidemiology of sorghum diseases in Central America: A case study. Pages 303-317 in: Proceedings, Sorghum and Millets Diseases, A Second World Review. W. A. J. de Millian, R. A. Frederiksen, and G. D. Bengston, eds. ICRISAT, Pataacheru, Andhra, Pradesh, India.

20. Williams, R. J. 1984. Downy mildews of tropical cereals. Pages 1-91 in: Advances in Plant Pathology, Vol. 2. D. S. Ingramm and P. H. Williams, eds. Academic Press, London. 